\title{
The link between Gastroesophageal Reflux Disease and Temporomandibular Disorder: A Systematic Review
}

\author{
Julia Janas ${ }^{1}$, Wioletta Urszula Bereziewicz ${ }^{2 *}$ and Katarzyna Szczeklik ${ }^{2}$ \\ ${ }^{1}$ Student Scientific Association, Department of Integrated Dentistry, Jagiellonian University Medical College, Kraków, Poland \\ ${ }^{2}$ Department of Integrated Dentistry, Jagiellonian University Medical College, Kraków, Poland
}

Submission: August 01, 2021; Published: August 13, 2021

*Corresponding author: Wioletta U Bereziewicz, Department of Integrated Dentistry, Jagiellonian University Medical College, Kraków, Poland

Abstract

Introduction: Temporomandibular disorder (TMD) is a group of pain-related disorders in the craniofacial region. Impairment associated with the jaw's function characterizes the condition, such as malocclusion, disfunction of mastication muscles and temporomandibular joint. In gastroesophageal reflux disease (GERD), the gastric acid content is refluxed to the oesophagus, and in many cases, toward the oral cavity leading to clinical symptoms. We aimed to assess the relationship between GERD and TMD based on a review of contemporary literature.

Methods: 240 studies were identified during the database search; an additional 17 were selected by hand. Abstracted screening selected 25 studies for in-depth analyses, out of which 10 were chosen for systematic review.

Results: The systematic review includes 1984 patients from 10 articles. The mean age of patients was 29 years. GERD was identified as a risk factor for TMD. Fifty per cent of studies have dealt with the treatment of GERD together with TMD. In three studies, omeprazole was used to treat GERD symptoms, and in one, there were advised against managing TMD with nonsteroidal anti-inflammatory drugs in GERD patients.

Conclusion: TMD can occur in patients with GERD. However, the relationship between both diseases has rarely been studied. Cooperation between doctors and dentists is recommended in treating patients with GERD and TMD, especially in selecting appropriate pharmacotherapy.

Keywords: Gastroesophageal reflux disease; temporomandibular disorder

Abbreviations: GERD: gastroesophageal reflux disease; TMJ: temporomandibular joint; TMD: temporomandibular disorder; NSAID: the nonsteroidal anti-inflammatory drug

\section{Introduction}

Gastroesophageal reflux disease (GERD) is an increasingly common gastrointestinal disorder with a prevalence of $10 \%$ to $20 \%$ in Western countries. The disease is characterised by typical reflux symptoms and reflux chest pain or syndromes caused by oesophagal injury, including reflux esophagitis, stricture, Barrett oesophagus or oesophagal adenocarcinoma. GERD symptoms might also be associated with several extraesophageal syndromes, including reflux cough, laryngitis, asthma, and dental erosion syndrome. Symptomatic GERD may be associated with chronic pain in the temporomandibular joint (TMJ), temporomandibular disorder (TMD), anxiety, somatisation and undermined sleep $[1,2]$. TMD is a group of pain-related disorders in the craniofacial region [1]. The cause of TMD has not been elucidated and changed from mechanistic to multifactorial and biopsychosocial in origin [1]. Impairment associated with the jaw's function characterises the condition, such as malocclusion, disfunction of mastication muscles, and temporomandibular joint [1]. It is a condition related to mental disorders (i.e., depression, anxiety, and undermined sleep) and complications associated with a previous jaw injury, incorrect posture, and a dysfunctional breathing pattern. One of the musculoskeletal therapy exercises used to manage symptoms of TMD includes the restoration of diaphragmatic breathing [3].

GERD is a gastrointestinal motility disorder that results from the reflux of gastric contents containing hydrochloric acid, pepsin and bile acids into the oesophagus or oral cavity, resulting in troublesome symptoms or complications [4]. This phenomenon results in damage to the oesophageal mucosa with typical heartburn, regurgitation, belching, chest pain and other complications [5]. Frequent and chronic refluxes of gastric acid content can cause injuries to the oropharyngeal cavity [5]. Tooth wear, linked to dental erosion, and chronic hoarseness, dry cough and wheeze, are noted as atypical symptoms among GERD patients 
[6]. Dental erosion related to GERD has been reported for over 80 years [7]. This dental injury is a progressive loss of hard dental tissues caused by chemical processes other than bacteria [8]. It is well established that gastric acid cause erosion of dental structures such as enamel and dentin [2]. Impaired salivary functions play an additional role in this condition [2]. Moreover, damage caused by erosion bears direct consequences on the occlusal surface and its eventual change, lead to pain-related issues, characterised as TMD. Although TMD has been scarcely studied in the context of GERD, its appearance among the affected group has been observed throughout the literature [5].

The other clinical disorder is bruxism, known otherwise as gridding of teeth, which is the tooth-to-tooth friction that results in dental wear [9]. The consequences of tooth wear are numerous, resulting in loss of vertical dimension, muscle pain and TMD [9]. Strong tooth wear in bruxism patients is observed in patients with long-term GERD [2]. Treatment of bruxism involves the management of a patient's GERD and TMD [9]. The treatment is challenging because bruxism and GERD may aggravate each other [2]. All conditions mentioned result in painful and uncomfortable sensations for the affected patients. A need for further investigation has been recognised to understand the link between GERD and TMD better. This report aims to analyse to what extent GERD is related to TMD. A systematic review was conducted by reviewing articles under predetermined research criteria and using online databases; ten articles were chosen for in-depth review.

\section{Method}

\section{Literature search}

The systematic review design modelled the Preferred Reporting Items for Systematic Reviews and Meta-Analyses (PRISMA) guidance. The authors followed the relevant PRISMA NMA checklist of items developed by Moher et al. [10]. It is an evidence-based minimum set of items used to assess reported health care interventions' benefits and harms. A systematic literature search was performed on GoogleScholar, PubMed, International Journal of Dentistry, Elsevier, and Cochrane Library from their inception until the $24^{\text {th }}$ of February 2021. The keywords "temporomandibular joint" and "gastroesophageal reflux"; "TMD" and "GERD"; "Le reflux gastro-œsophagien (GRO)" and "Les troubles temporo-mandibulaires (TMD)" were used to distinguish relevant articles. The language of the study was chosen as English, French and Polish. Supplementary articles were selected by hand from the reference lists to complement these records.

\section{Study identification}

Solely studies investigating patients attained with GERD and TMD were chosen for review. After the database search, 240 studies were identified, an additional 17 were selected by hand. Abstract screening permitted the selection of 25 studies for indepth analyses, out of which 10 were chosen for systematic review.

\section{Risk of bias assessment}

The authors assessed the content of the chosen studies. A literature search in several different languages served to minimise bias.

\section{Data extraction and statistical analysis}

Data was extracted concerning the following characteristics: the number of subjects in the study, age, gender, additional health conditions, the prevalence of GERD and TMD, the treatment and its outcomes. Statistical analysis and creation of figures were performed using the software Microsoft Excel for IOS (version 2.46).

\section{Results}

PRISMA flow diagram is presented in Figure 1 Online database included 240 papers and hand-picked 17 publications. If more than one exclusion criterion could be applied, the study was eliminated in the pertaining category. Another reason for exclusion was insufficient information on TMD and GERD (Table 1).

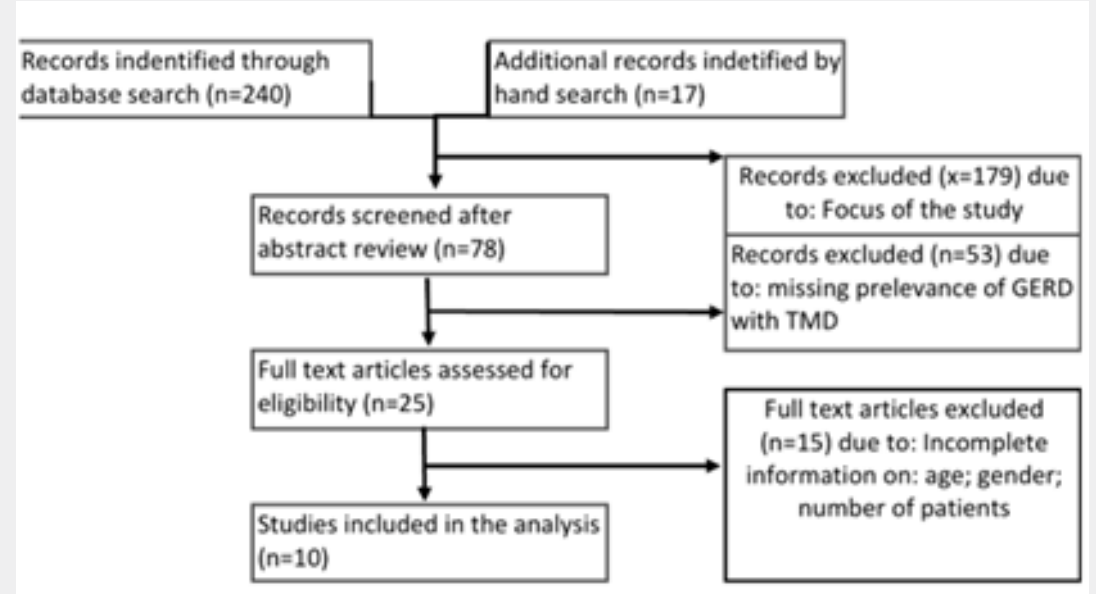

Figure 1: The flow chart for the study. TMD - temporomandibular disorder. 
Table 1: Characteristics of data analysed in the study on the basis of 10 publications related to GERD and TMD.

\begin{tabular}{|c|c|c|c|c|c|c|}
\hline Article & $\begin{array}{l}\text { Number of } \\
\text { patients } \\
\text { examined }\end{array}$ & Age & Gender & $\begin{array}{l}\text { Additional health condi- } \\
\text { tions }\end{array}$ & Treatment proposed & Outcomes \\
\hline$[4]$ & 3 & $25,33,39$ & $\begin{array}{l}2 \text { male } 1 \\
\text { female }\end{array}$ & $\begin{array}{l}\text { Dental erosion } \\
\text { Erythemateous lesion } \\
\text { Tongue burning } \\
\text { GERD }\end{array}$ & $\begin{array}{l}\text { Short term and managing } \\
\text { of GERD }\end{array}$ & Unknown \\
\hline [9] & 1 & 42 & Female & Smoker GERD & $\begin{array}{c}\text { Omeprazole } \\
\text { Restoration of dental } \\
\text { aesthetics }\end{array}$ & $\begin{array}{l}\text { Occlusal balance achieved } \\
\text { TMD symptoms "had almost } \\
\text { completely disappeared" } \\
\text { with rare instances of muscle } \\
\text { tenderness. } \\
\text { GERD is controlled by pharma- } \\
\text { cological therapy }\end{array}$ \\
\hline [12] & 1 & 73 & Female & $\begin{array}{c}\text { Dysphagia } \\
\text { Dysarthria } \\
\text { Dislocation of TMJ after } \\
\text { GERD-related vomiting } \\
\text { Right hemiparesis } \\
\text { Poor oral hygiene }\end{array}$ & $\begin{array}{c}\text { Captopril } \\
\text { Prazosin hydrochloride } \\
\text { Nifedipine } \\
\text { Clostridium butyricum } \\
\text { Omeprazole } \\
\text { Sennoside } \\
\text { Rehabilitation activities } \\
\text { for dysphagia }\end{array}$ & $\begin{array}{l}\text { No new TMJ dislocation during } \\
\text { the subsequent 6-months }\end{array}$ \\
\hline [13] & 1 & 35 & Female & $\begin{array}{c}\text { Systemic sclerosis } \\
\text { Raynaud syndrome } \\
\text { Mild pulmonary fibrosis } \\
\text { GERD } \\
\text { Hypothyroidism } \\
\text { Anxiety } \\
\text { Bilateral mandibular con- } \\
\text { dyles }\end{array}$ & $\begin{array}{c}\text { Omeprazole } \\
\text { Levothyroxine } \\
\text { Nifedipine } \\
\text { Naproxen } \\
\text { Domperidone } \\
\text { Orthodontic treatment } \\
\text { Surgical treatment: jaw } \\
\text { reconstruction surgery; } \\
\text { bilateral total TMJ recon- } \\
\text { struction }\end{array}$ & $\begin{array}{l}\text { No new TMJ dislocation during } \\
\text { the subsequent } 6 \text {-months }\end{array}$ \\
\hline [1] & 1522 & $\begin{array}{l}18 \text { to } 70 \\
\text { mean age } \\
\quad 27\end{array}$ & $\begin{array}{c}\text { Mixed } \\
1048 \text { female } \\
474 \text { male }\end{array}$ & $\begin{array}{c}\text { Anxiety } \\
\text { Somatization } \\
\text { Disturbances in sleeping } \\
\text { GERD }\end{array}$ & None & None \\
\hline$[5]$ & 60 & $\begin{array}{l}\text { Mean age } \\
41.4 ; \\
\text { range } 19 \\
\quad \text { to } 66\end{array}$ & $\begin{array}{l}\text { Mixed } \\
34 \text { female } \\
26 \text { male }\end{array}$ & $\begin{array}{l}\text { Myofascial pain } \\
\text { Disc displacement } \\
\text { Bruxism } \\
\text { GERD }\end{array}$ & $\begin{array}{l}\text { Caution to prescribe } \\
\text { NSAID for TMDs symp- } \\
\text { toms in GERD patients. } \\
\text { NSAID aggravate GERD. }\end{array}$ & None \\
\hline$[14]$ & 1 & 57 & Male & $\begin{array}{l}\text { Hypertension } \\
\text { Hepatitis C } \\
\text { Hyperlipidemia } \\
\text { GERD }\end{array}$ & $\begin{array}{l}\text { Operative treatment of } \\
\text { synovial cyst of the TMD } \\
\text { resulted in TMJ dysfunc- } \\
\text { tion }\end{array}$ & TMJ dysfunction \\
\hline$[2]$ & 363 & $\begin{array}{l}18 \text { to } 72 ; \\
\text { mean age } \\
\quad 31\end{array}$ & Mixed & $\begin{array}{c}\text { GERD } \\
\text { Bruxism } \\
\text { Tooth wear } \\
\text { Pain-related TMD } \\
\text { Depression } \\
\text { Anxiety } \\
\text { Sleep apnea } \\
\text { Impaired sleep quality }\end{array}$ & None & $\begin{array}{l}\text { Long term GERD is a risk factor } \\
\text { for bruxism }\end{array}$ \\
\hline [11] & 60 & $\begin{array}{l}\text { Mean age } \\
50.92\end{array}$ & Mixed & $\begin{array}{c}\text { Dental erosion } \\
\text { GERD } \\
\text { Halitosis }\end{array}$ & None & None \\
\hline [15] & 10 & $\begin{array}{l}\text { Mean age } \\
9.2 ; \text { range } \\
5 \text { to } 15\end{array}$ & $\begin{array}{c}\text { Mixed } \\
\text { (5 girls and } \\
5 \text { boys })\end{array}$ & Bruxism & $\begin{array}{l}\text { No relation between GERD } \\
\text { and bruxism in children }\end{array}$ & None \\
\hline
\end{tabular}




\section{Patient characteristics}

The systematic review incorporated 1984 patients from 10 articles, ranging from 1 case study to 1522 . Patients ages range from 5 to 73 years. At the same time, the mean age was 29 years. Both genders were included in the study; however, there is a higher ratio of women to men noted throughout multiple studies $[1,5,11]$.

\section{Additional health conditions}

All studies noted additional health conditions of the analyzed patients other than TMD and GERD [1,2,4, 5,9,11-15]. Two studies noted the presence of erosion, while in others, it is an exclusion criterion $[2,4,11]$. One study performed in children did not find any association between GERD and bruxism, nor TMD [15]. Other conditions included: bruxism, erythematous lesions of the oral mucosa, tongue burning, smoking, dysphagia, dysarthria, dislocation of TMJ after GERD-related vomiting, right hemiparesis, poor oral hygiene, systemic sclerosis, Raynaud syndrome, mild pulmonary fibrosis, hypothyroidism, anxiety, bilateral mandibular condyles, somatisation, disturbances in sleeping myofascial pain, disc displacement, hypertension, hepatitis C, hyperlipidemia, tooth wear, depression, sleep apnea, and halitosis.

\section{Treatment proposed and outcomes}

In $60 \%$ of all articles, authors proposed treatment for patients $[4,5,9,12-14]$. In half of the studies, patients with GERD were treated with TMD $[4,5,9,12,13]$. In three studies, a proton pump inhibitor (omeprazole) was used to treat GERD symptoms $[9,12,13]$, and in one, authors advised not to manage TMD pain with nonsteroidal anti-inflammatory drug (NSAID) in GERD patients [5]. In one study there were tested the effects of placebo occlusal treatment [16]. In $50 \%$ of articles, patients required concurrent treatment of other medical conditions [4,9,12-14]. Other treatments include several medications prescribed in various clinical conditions like captopril, prazosin hydrochloride, nifedipine, sennoside, levothyroxine, naproxen, domperidone, rehabilitation activities for dysphagia, and procedures like orthodontic treatment and surgical therapy including jaw reconstruction procedure and bilateral total TMJ reconstruction. Fifty percent of all articles described the treatment outcome $[2,9,12-14]$. In four studies, authors observed amelioration of the patient's condition $[2,9,12,13]$. Neis et al. noted an increased TMJ dysfunction after synovial cyst operation [14].

\section{Discussion}

It is estimated that around one-fifth of the general adult population suffers from TMD and GERD $(20 \%$ and $22 \%$, respectively) $[17,18]$. Both conditions are common. Therefore, dental practitioners should recognize the need for comorbid treatment [4]. Despite the prevalence of GERD and TMD concurrent findings in medical literature, few articles pertain to their link. Gharaibeh et al. found that GERD patients were twice more likely than the control group to be affected by TMD $(31,7 \%$ of GERD patients and 15\% of the control, the data was statistically significant) [5]. Both conditions share a similar risk factor which is depression. Therefore, it is essential to note that none of the subjects was diagnosed with severe depression, and only a small percentage had moderate depression. However, the authors noted a reserved approach to mental health in studied groups $[5,19,20]$. Causes of orofacial muscle pain are beyond psychological factors, as they can arise from muscle fatigue due to bruxism and nocturnal GERD episodes [21]. Several studies revealed quadruples prevalence of somatisation in GERD patients, while others have found similar or slightly lower results (from 25\% to $31 \%$ frequency in the affected groups) [5]. GERD patients report higher pain levels due to TMD, although this does not translate into higher levels of TMJ disability.

Patients with TMD are mostly managed with NSAID [22]. These over-the-counter medications are known to damage the gastrointestinal tract mucosa, including the oesophagus, aggravating reflux oesophagitis and GERD symptoms [23]. Therefore, dental practitioners should consider the likelihood of TMD in some patients being affected by GERD. They should divulge patients about NSAID possible side effects and propose additional or alternative remedies, such as physical therapy, prosthodontics, and gastroenterological consultation [5]. Bartley has proposed restoration of diaphragmatic breathing, which is an important musculoskeletal and psychological therapy, helping GERD patients with TMD [3]. So-called posture therapy, breathing techniques and instructions for relaxation of diaphragmatic breathing may decrease TMD symptoms in GERD patients [3]. Other possible clinical situations are likely to cause episodes of TMD, including procedures requiring the wide opening of mouth for a longer time, such as endoscopy or extraction of third molars $[24,25]$. Post-procedure muscle fatigue and spasm have been noted in both situations $[24,25]$.

Li et al. examined the link between GERD, bruxism, and tooth wear [2]. They found that chronic TMD is associated with GERD, providing empirical data on the link between both diseases, contrasting to previous studies where such findings were majority descriptive [1]. The authors noted that although these findings are consistent with other observations, they did not prove causation between GERD and TMD [1]. Moreover, recognising based on literature that bruxism and tooth wear are associated throughout literature with TMD due to resulting muscle overexertion and malocclusion, the authors would like to point out its relevance in the context of GERD. Forssel et al. tested placebo effectiveness of occlusal treatment and have noted some amelioration among this group; however, relief of symptoms was statistically more significant in the treatment group $[16,26]$. Several authors indicate that nocturnal gastroesophageal reflux makes the patient prone to sleep bruxism, and untreated chronic refluxes may result in severe tooth wear over time $[2,27,28]$. Polysomnography studies confirmed that GERD patients exhibit an increased likelihood of severe tooth wear due to sleep bruxism and not only tooth erosion 
caused by reflux of gastric acid contents [2,29]. Herrera et al. examined the association between GERD and bruxism in children; however, they had not found significant data to support the same phenomenon as in adults [15].

Loss of dental surface in GERD patients is caused by endogenous corrosion [9]. Perimolysis corrosion is most severe in the palatal surfaces of anterior maxillary teeth and at the buccal surfaces of posterior teeth [9]. The consequences in the oral environment caused by refluxed gastric acid attacks have been described. Respiratory symptoms, such as chronic hoarseness or cough, laryngitis, and a lack of dental pellicle with the subsequent demineralised tooth surface, are mostly observed [30]. In severe cases, patience with gastroesophageal reflux-related vomiting may cause dislocation of the TMJ [12]. Dental treatment modalities may not eliminate bruxism, as this condition involves hereditary, systematic, local, and psychological factors [31]. Pullinger et al. and other authors have noted that patients with bruxism have an increased likelihood of TMD [2,32]. Occlusal stability must be protected. Else, the clinical longevity of the dental restoration is reduced [9]. Ranjitkar et al. have found that the median prevalence of tooth erosion in patients with GERD is $24 \%$ [30]. The authors noted that dental practitioners might be the first physicians to diagnose the possibility of GERD [30]. As a result, there is a need to raise awareness of its various manifestations in the oral cavity [30]. Pace et al. reviewed seventeen case-controlled studies, observing a strong correlation between the occurrence of dental erosion and GERD. However, the severity of tooth loss and TMD symptoms varied considerably among the studied groups [33]. There is a complex connection between musculoskeletal diseases, GERD, mental disorders, and sleep-related conditions. However, the significance of one condition over the other is ambiguous [1]. The authors had been surprised by the scarceness of articles dedicated to the link between GERD and TMD, and only a slightly more numerous amounts of studies touching upon it. Further research in the domain is strongly encouraged to manage TMD in dental practice and multidisciplinary treatment.

\section{Conclusion}

Gastroesophageal reflux disease is associated not only with oral cavity manifestations but also with the temporomandibular joint disorder. Dental practitioners should be conscious of the risk factors, symptoms, and signs of TMD, and there is a necessity for close cooperation between medical and dental practitioners when treating GERD and TMD patients.

\section{References}

1. Li Y, Fang M, Niu L, Yu Fan, Yan Liu, et al. (2019) Associations among gastroesophageal reflux disease, mental disorders, sleep and chronic temporomandibular disorder: a case-control study. CMAJ 191: E909915.

2. Li Y, Yu F, Niu L, Wei Hu, Yong Long, et al. (2018) Associations among Bruxism, Gastroesophageal Reflux Disease, and Tooth Wear. J Clin Med 7(11): 417.
3. Bartley JR (2019) Gastroesophageal reflux disease, temporomandibular disorders, and dysfunctional breathing. CMAJ 191: E1255.

4. Chi AC, Neville BW, Krayer JW (2010) Oral manifestations of systemic disease. Am Fam Physician 82(11): 1381-1388.

5. Gharaibeh TM, Jadallah K, Jadayel FA (2010) Prevalence of Temporomandibular Disorders in Patients with Gastroesophageal Reflux Disease: A Case-Controlled Study. J Oral Maxillofac Surg 68(7):1560-1564.

6. Wetselaar P, Manfredini D, Ahlberg J, Anders Johansson, Ghizlane Aarab, et al. (2019) Associations between tooth wear and dental sleep disorders: A narrative overview. J Oral Rehabil 46: 765-775.

7. Pasalar M, Firouzmandi M, Saberifiroozi (2015) Gastroesophageal Reflux Disease and Dental Erosion Correlation; a New Theory from Ancient Time. Revista Espanola De Enfermedades Digestivas: Organo Oficial De La Sociedad Espanola De Patologia Digestiva, U.S. National Library of Medicine.

8. Baskan S, Dundar B, Altun S, Ulku R, Kaya S (2006) The Importance of Gastroesophageal Reflux Disease in Dentistry. Biotechnology \& Biotechnological Equipment 20(2): 146-150.

9. Machado NA, Fonseca RB, Branco CA, Barbosa GA, Fernandes Neto AJ, et al. (2007) Dental wear caused by association between bruxism and gastroesophageal reflux disease: a rehabilitation report. J Appl Oral Sci 15(4): 327-333.

10. Moher D, Liberati A, Tetzlaff J (2009) Preferred reporting items for systematic reviews and meta-analyses: the PRISMA statement. Ann Intern Med 151: 264-269.

11. Roesch-Ramos L, Roesch-Dietlen F, Remes-Troche JM, et al. (2014) Dental erosion, an extraesophageal manifestation of gastroesophageal reflux disease. The experience of a center for digestive physiology in South- eastern Mexico. Rev Esp Enferm Dig 106: 92-97.

12. Kaneko T, Endo M, Uematsu A, Nakamura S, Horie N, Shimoyama T (2016) Temporomandibular joint dislocation in a post-stroke patient with dysphagia caused by gastroesophageal reflux-related vomiting. J Oral Sci 58(1):133-136.

13. Doucet JC, Morrison AD (2011) Bilateral mandibular condylysis from systematic sclerosis: case report of surgical correction with bilateral total temporomandibular joint replacement. Craniomaxillofac Trauma Reconstr 4(1): 11-18.

14. Neis J, Tehrani M, Dornhoffer LJ (2010) Synovial cyst of the temporomandibular joint: An Unusual Presentation. Case Report. Int. Adv Otol 6:(1) 116-119.

15. Herrera M, Valencia I, Grant M (2006) Bruxism in children: effect on sleep architecture and daytime cognitive performance and behavior. SLEEP 29(9):1143-1148.

16. Forssel H, Kirveskari P, Kangasniemi P (1986) Effect of occlusal adjustment on mandibular dysfunction. A double-blind study. Acta Odontol Scand 44(2): 63-69.

17. Locke GR, Talley NJ, Fett SL, et al. (1997) Prevalence and clinical spectrum of gastroesophageal reflux: A population-based study in Olmsted County, Minnesota. Gastroenterology 112: 1448.

18. De Kanter RJ, Kayser AF, Battistuzzi PG (1992) Demand and need for treatment of craniomandibular dysfunction in the Dutch adult population. J Dent Res 71:1607-1612.

19. Yap AU, Dworkin SF, Chua EK (2003) Prevalence of temporomandibular disorder subtypes, psychologic distress, and psychosocial dysfunction in Asian patients. J Orofac Pain. Winter 17(1): 21-28. 


\section{Advances in Dentistry \& Oral Health}

20. Hamdi E, Amin Y, Abou-Saleh MT (1997) Problems in validating endogenous depression in the Arab culture by contemporary diagnostic criteria. J Affect Disord 44(2-3): 131-143.

21. Miyawaki S, Tanimoto Y, Araki Y (2003) Association between nocturnal bruxism and gastroesophageal reflux. Sleep 26: 88.

22. Ta LE, Dionne RA (2004) Treatment of painful temporomandibular joints with a cyclooxygenase-2 inhibitor: A randomized placebocontrolled comparison of celecoxib to naproxen. Pain 111(1-2): 13-21.

23. Gutthann SP, García Rodríquez LA, Raiford DS (1997) Individual nonsteroidal antiinflammatory drugs and other risk factors for up- per gastrointestinal bleeding and perforation. Epidemiology 8(1): 18-24

24. Min BH, Lee H, Jeong JS, et al. (2008) Comparison of a novel teethprotecting mouthpiece with a traditional device in preventing endoscopy-related complications involving teeth or temporomandibular joint: A multicenter randomized trial. Endoscopy 40(6): 472-427.

25. Huang GJ, Rue TC. (2006) Third-molar extraction as a risk factor for temporomandibular disorder. J Am Dent Assoc 137(11): 1547-1554.

26. Barbosa, Gustavo Augusto Seabra (2016) The role of occlusion and occlusal adjustment on temporomandibular dysfunction. Brazilian Journal of Oral Sciences 589-594.
27. Watanabe M, Nakatani E, Yoshikawa H, Kanno T, Nariai Y, et al. (2017) Oral soft tissue disorders are associated with gastroesophageal reflux disease: Retrospective study. BMC Gastroenterol 17: 92.

28. Mengatto CM, Dalberto Cda S, Scheeren B, Barros SG (2013) Association between sleep bruxism and gastroesophageal reflux disease. J. Prosthet. Dent 110(5): 349-355.

29. Okura K, Shigemoto S, Suzuki Y, Noguchi N, Omoto K, et al. (2017) Mandibular movement during sleep bruxism associated with current tooth attrition. J Prosthodont Res 61(1): 87-95.

30. Ranjitkar S, Kaidonis JA, Smales RJ (2012) Gastroesophageal reflux disease and tooth erosion. Int J Dent 2012: 479850.

31. Harada T, Ichiki R, Tsukiyama Y, Koyano K (2006) The effect of oral splint devices on sleep bruxism: a 6-week observation with an ambulatory electromyographic recording device. J Oral Rehabil 33(7): 482-488.

32. Pullinger AG, Seligman DA, Gornbein JA (1993) A multiple logistic regression analysis of the risk and relative odds of temporomandibular disorders as a function of common occlusal features. J Dent Res 72(6): 968-979.

33. Pace F, Pallotta S, Tonini M, Vakil N, Bianchi Porro G (2008) Systematic review: gastro-oesophageal reflux disease and dental lesions. Aliment Pharmacol Therap 27 (12): 1179-1186.

This work is licensed under Creative Commons Attribution 4.0 License DOI: 10.19080/ADOH.2021.14.555896

\section{Your next submission with Juniper Publishers} will reach you the below assets

- Quality Editorial service

- Swift Peer Review

- Reprints availability

- E-prints Service

- Manuscript Podcast for convenient understanding

- Global attainment for your research

- Manuscript accessibility in different formats

( Pdf, E-pub, Full Text, Audio)

- Unceasing customer service

Track the below URL for one-step submission https://juniperpublishers.com/online-submission.php 